\title{
Multifocal nodular hypertrophy of trigeminal nerve in multifocal acquired demyelinating sensory and motor neuropathy
}

Motoi Kuwahara, MD, PhD, Isao Numoto, MD, and Susumu Kusunoki, MD, PhD

Neurol Neuroimmunol Neuroinflamm 2019;6:e553. doi:10.1212/NXI.0000000000000553

A 60-year-old woman presented with asymmetric distal limb weakness and muscle atrophy. Electrophysiologic study revealed demyelinating polyneuropathy, and she was diagnosed with multifocal acquired demyelinating sensory and motor (MADSAM) neuropathy as a subtype of chronic inflammatory demyelinating polyneuropathy (CIDP) based on the established diagnostic criteria. ${ }^{1}$ Anti-neurofascin 155 antibody was negative. Cervical and lumbosacral nerve roots showed asymmetric multifocal hypertrophy (figure 1), which were distinct from those in typical CIDP. ${ }^{2}$ Brain MRI revealed multifocal nodular hypertrophy of trigeminal nerves (figure 2 and video 1). These hypertrophic patterns in trigeminal nerves as well as nerve roots might be characteristics of MADSAM neuropathy.

\section{Author contributions}

M. Kuwahara has contributed to the acquisition, analysis, and interpretation of data and drafted the article. I. Numoto has analyzed and interpreted data. S. Kusunoki has made substantial contributions to the conception and design of the study and also revised the paper critically for important intellectual content. S. Kusunoki provided the final approval to the paper.

\section{Study funding}

No targeted finding reported.

\section{Disclosure}

M. Kuwahara received speaker honoraria from Teijin, Nihon, and Japan Blood Products Organization. I. Numoto reports no disclosures. S. Kusunoki received speaker honoraria from Teijin, Nihon, Japan Blood Products Organization, Biogen, Novartis, Dainippon Sumitomo, Kyowa Kirin, Ono Pharma, Pfizer, Alexion, and Chugai; served on the editorial board for Journal of Neuroimmunology, Neurology; served as Editor-in-Chief for Neurology and Clinical Neuroscience; received research support from Novartis, Dainippon Sumitomo, Sanofi, Japan Blood Products Organization, Ohtsuka, Kyowa Kirin, Daiichi Sankyo, Eisai, Takeda, and Nihon; received research support from Ministry of Education, Culture, Sports, Science and Technology of Japan and Japan Agency for Medical Research and Development. Disclosures available: Neurology.org/NN.

\section{Publication history}

Received by Neurology: Neuroimmunology \& Neuroinflammation January 4, 2019. Accepted in final form January $28,2019$.

\section{References}

1. Joint Task Force of the EFNS and the PNS. European Federation of Neurological Societies/Peripheral Nerve Society Guideline on management of chronic inflammatory demyelinating polyradiculoneuropathy; report of a Joint Task Force of the European Federation of Neurological Societies and the Peripheral Nerve Society. J Peripher Nerv Syst 2010;15:1-9.

2. Shibuya K, Sugiyama A, Ito S, et al. Reconstruction magnetic resonance neurography in chronic inflammatory demyelinating polyneuropathy. Ann Neurol 2015;77:333-337.

\author{
Correspondence \\ Dr. Kusunoki \\ kusunoki-tky@umin.ac.jp
}

MORE ONLINE

Video 
Figure 1 Cervical and lumbosacral nerve roots hypertrophy
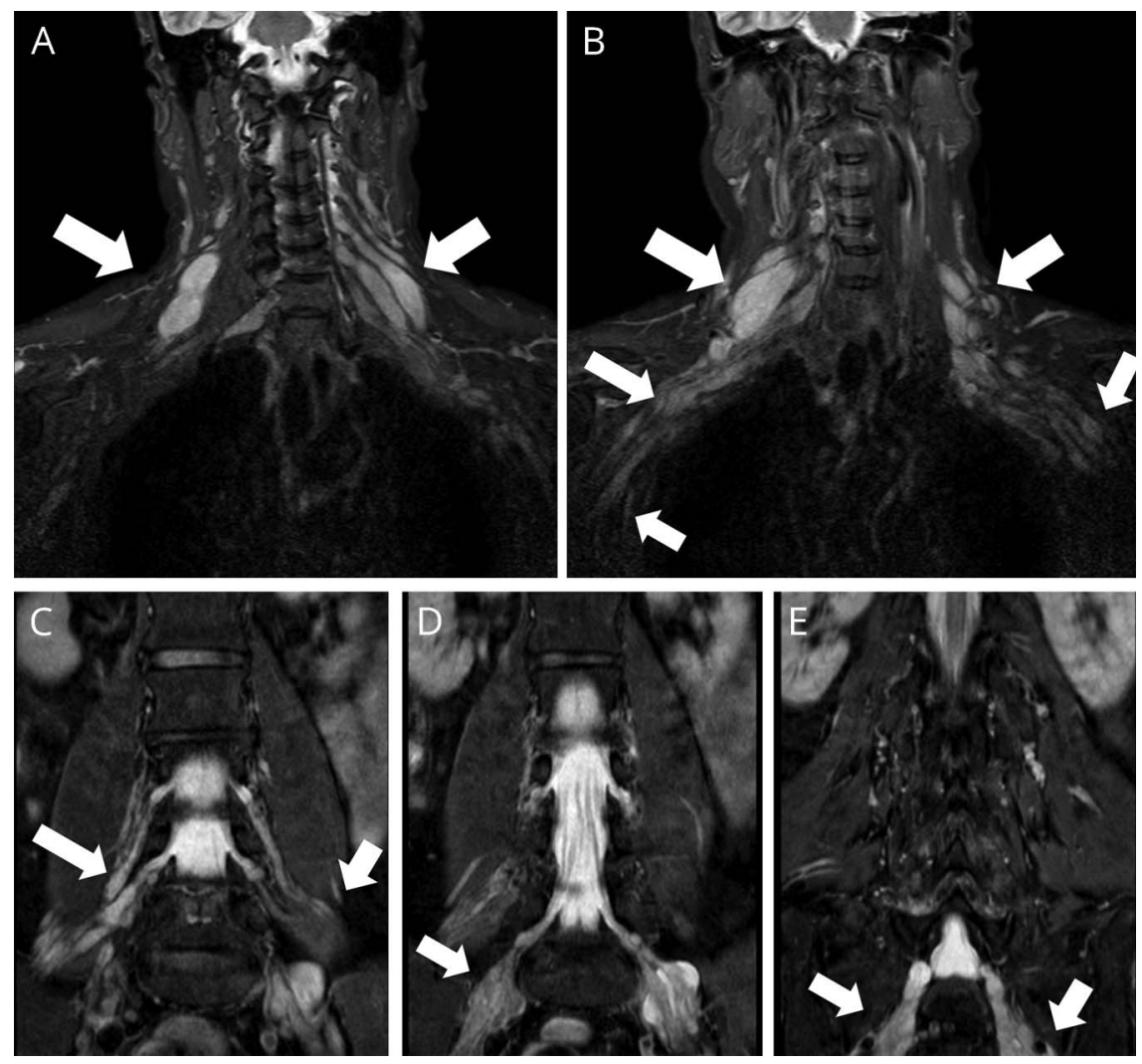

(A and B) Coronal cervical STIR MRI; (C-E), coronal lumbar STIR MRI. STIR = short tau inversion recovery.

Figure 2 Trigeminal nerves hypertrophy
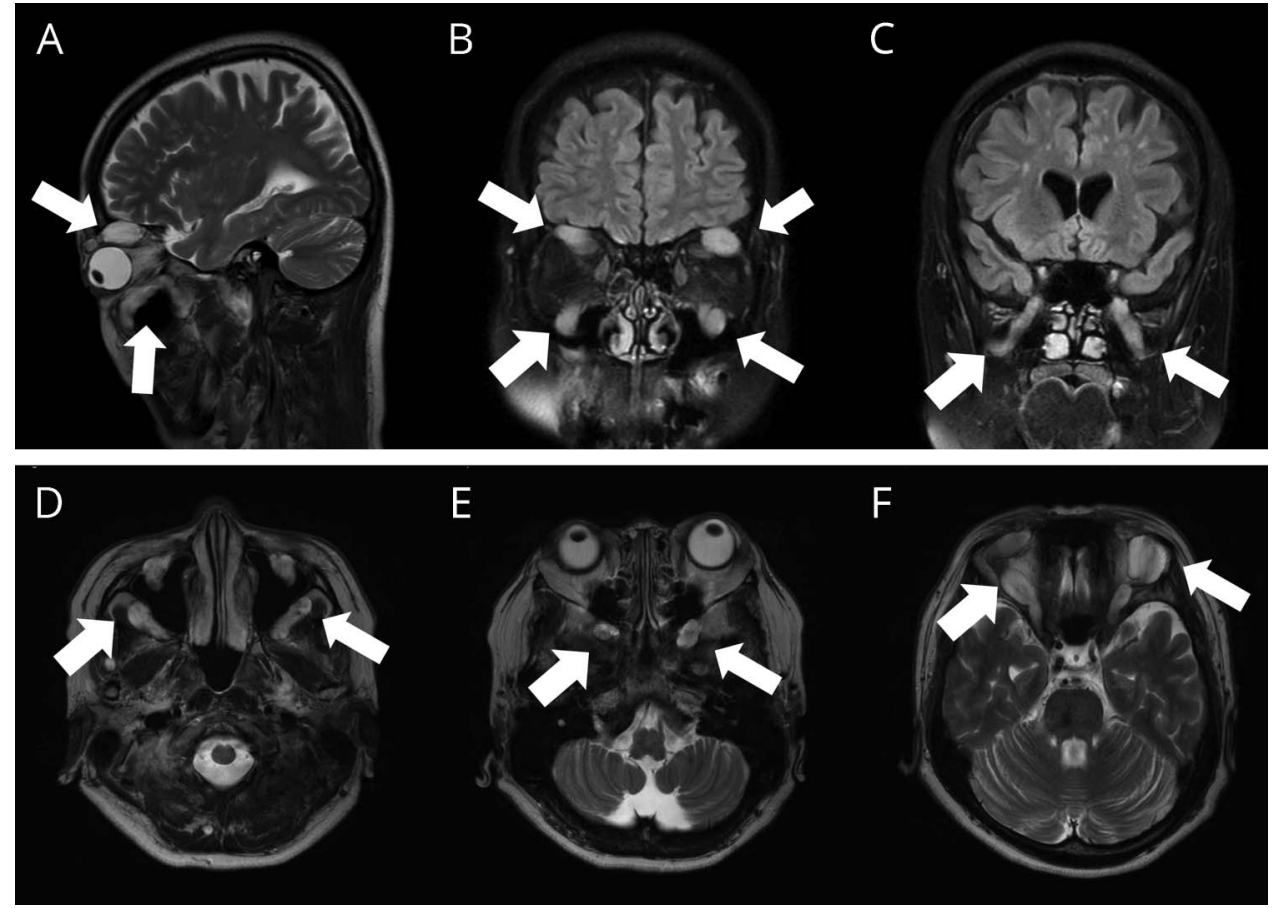

(A) Sagittal T2-weighted MRI; (B and C) coronal fluid-attenuated inversion recovery MRI; (D-F) axial T2-weighted MRI. 


\title{
Neurology \\ Neuroimmunology \& Neuroinflammation
}

\author{
Multifocal nodular hypertrophy of trigeminal nerve in multifocal acquired \\ demyelinating sensory and motor neuropathy \\ Motoi Kuwahara, Isao Numoto and Susumu Kusunoki \\ Neurol Neuroimmunol Neuroinflamm 2019;6; \\ DOI 10.1212/NXI.0000000000000553
}

This information is current as of April 1, 2019

\section{Updated Information \& Services}

References

Subspecialty Collections

Permissions \& Licensing

Reprints including high resolution figures, can be found at:

http://nn.neurology.org/content/6/3/e553.full.html

This article cites 2 articles, 0 of which you can access for free at: http://nn.neurology.org/content/6/3/e553.full.html\#\#ref-list-1

This article, along with others on similar topics, appears in the following collection(s):

Chronic inflammatory demyelinating polyneuropathy

http://nn.neurology.org//cgi/collection/chronic_inflammatory_demyeli nating_polyneuropathy

MRI

http://nn.neurology.org//cgi/collection/mri

Information about reproducing this article in parts (figures,tables) or in its entirety can be found online at:

http://nn.neurology.org/misc/about.xhtml\#permissions

Information about ordering reprints can be found online:

http://nn.neurology.org/misc/addir.xhtml\#reprintsus

Neurol Neuroimmunol Neuroinflamm is an official journal of the American Academy of Neurology.

Published since April 2014, it is an open-access, online-only, continuous publication journal. Copyright

Copyright (C) 2019 The Author(s). Published by Wolters Kluwer Health, Inc. on behalf of the American

Academy of Neurology.. All rights reserved. Online ISSN: 2332-7812.

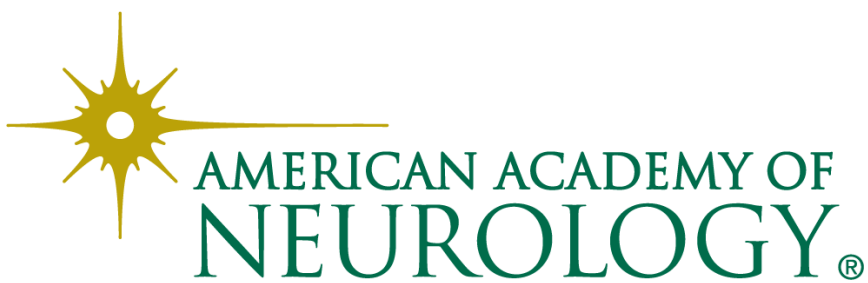

